\title{
Theories of International Balancing, the Rise of China, and Political Alignments in the Asia Pacific
}

\author{
Joseph M. Grieco
}

\begin{abstract}
How are China's neighbors and other states reacting to growing Chinese power? This question is addressed through an analysis of alignment toward or away from China on the one hand, and toward or away from the United States on the other hand, by eight U.S. Asia-Pacific allies, four memberstates of the Association of South East Asian Nations, China's four partners in the BRICS informal arrangement, and a random sample of twenty-four countries from around the world. Two main indicators of alignment are examined: a measure of growing similarity and dissimilarity of alliance portfolios between 1972 and 2007; and a measure of affinity between countries in their voting in the United Nations General Assembly between 1972 and 2012. There appear to be some early signs of comprehensive balancing against China by some states, and especially by U.S. Asia-Pacific allies. However, there remains substantial fluidity in alignment between China and the United States by other countries, and thus diplomatic opportunities remain to prevent polarization of relations in the Asia-Pacific in the face of growing Chinese power.
\end{abstract}

Key Words: Asia-Pacific diplomacy, China, United States, military alliances, United Nations

S cholars of international relations and analysts of foreign-policy have been concerned about a rising China for at least the past two decades (see, for example, Friedberg 1993/94; 1995; 2011; Betts 1993/94; Mearsheimer 2001; Goldstein 2005; 2013; Christensen 1999; 2006; 2011). They have been particularly interested in trying to estimate whether a more powerful China will contribute to peace and security or tensions and the risk of war in the Asia-Pacific

*Joseph M. Grieco (grieco@duke.edu) is Professor of Political Science at Duke University. He is the author of Cooperation Among Nations: Europe, America, and Non-Tariff Barriers to Trade, and is the the co-author (with G. John Ikenberry) of State Power and World Markets: The International Political Economy. Articles and notes by him have appeared in Journal of Conflict Resolution, International Studies Quarterly, Security Studies, American Political Science Review, International Organization, and World Politics.

I wish to thank Jaechul Kim for his helpful comments on an earlier draft of this essay. I received additional helpful comments at the Annual Conference of the Korean Association of International Studies (December 2013) as well as at seminars at the School of International Service at American University and the University of Torino.

The Korean Journal of International Studies Vol.12 Special Issue (May 2014), 15-48. 
region. This general issue of the consequences of growing Chinese power translates into two more specific questions. First, how will China define its interests and act towards others as it attains a preeminent position in the distribution of world power? Second, how will China's neighbors and other countries, and in particular the United States, react to a Chinese foreign policy that reflects that country's growing power?

The answer to the first question has become increasingly clear: during the past twenty years, China has been reacting to its growing relative power as many other states in the past have reacted when they have grown in strength, namely, it has expanded the scope of what it takes to be its important interests, and it has used different elements of power, including military power, to advance those more ambitiously defined national interests. ${ }^{1}$ For example, during the past two decades, and especially during the past few years, China has made it clear that it should have sovereignty over much of the East China Sea and the South China Sea (Swain and Fravel 2011; Goldstein 2013; Dupuy and Dupuy 2013; Beckman 2013), and it has taken numerous steps, including the use of low levels of military force, to assert that claim over those two large areas.

What about the second question: how have China's neighbors and other states been reacting to growing Chinese power? It is this second question that is addressed in the analysis that follows. In seeking to address that question, we may begin to confront the central problem of whether a rising China means trouble for the Asia-Pacific.

The analysis below of how a range of states have been reacting to a progressively more powerful China will proceeds in three steps. We begin in the next section with a discussion of a selection of major international relations writings on the matter of how the rise of one state might induce changes in the foreign policy alignments in other states. Much of our attention will be on different variants of power-balancing theory, some but not all of which are situated in the realist tradition. In addition, we will examine analyses that suggest that the domestic institutions of states are likely to influence the manner in which they will be able to coordinate their reaction to the rising power of a new challenger.

The second step in the analysis, developed in the subsequent main section of the essay, consists of an effort to ascertain whether we can identify major changes in relative capabilities of states, and if we can actually pinpoint the emergence of a rising state. We also seek to determine if we can employ some

\footnotetext{
${ }^{1}$ Alastair Smith (2013) has helpfully pointed out that the media's increasing emphasis since 2010 on Chinese assertiveness probably understates Chinese objectives and willingness to press its claims prior to that year and perhaps overstates Chinese goals and behavior since then.
} 
systematic measure of political reactions by other states to the rise of that rising state. This effort focuses on the years prior to World War I. On the one hand, an effort is made to determine whether the employment of a well-known indicator from the Correlates of War data project, the Composite Index of National Capabilities (CINC), tracks the relative rise of Germany during the late- $19^{\text {th }}$ and early $20^{\text {th }}$ centuries, since in most historical narratives Germany is viewed as the main challenger to the international status quo of that era (Clark 2013; Macmillan 2013). On the other hand, we use a measure of growing alliance similarity and dissimilarity, S, to determine if it can track in the years up to 1914 the growing division of Europe into two rival blocs, Germany/Austria-Hungary (with Italy as a faux ally) on the one hand and France/Britain/Russia on the other. As we will see, to a reasonable degree, CINC and S seem to capture key trends - rising German power and growing polarization of European alliance structures - that probably reflected and in turn positively contributed to the buildup of tensions in pre-war Europe. The inference we can draw from this analysis of pre-World War I Europe is that we might profitably employ the CINC measure to track growing Chinese relative power, and we can use alliance Sscores to capture changes, if any, in the alignment of states in response to that growing Chinese power.

This effort to see if CINC and S-scores can be employed to track Chinese relative power and possible state reactions to it is pursued in the third and final main section of the essay. The current series of S-scores ends with the year 2007. Although by consequence we are unable to examine trends in alliance choices up to the very present, the cut-off date of 2007 for S-scores allows us nonetheless to see how states have been reacting to growing Chinese power for a period covering almost three decades since China made its fundamental break from a state-controlled to a market-based economy; it allows us to examine how states reacted during the special decade of the 1990s, during which we will see that China experienced a massive surge in relative power (The CINC index); and it allows us to track state reactions to growing Chinese power for almost two decades of the immediate post-Cold War era. However, we will see below that China's relative power continued to grow throughout the first decade of the 2000s, and we would certainly like to know if states have been reacting to that continued relative enhancement of power beyond 2007. Hence, in addition to a tracking of S-scores, we will employ a second measure of foreign policy alignment, namely, similarity in voting by states in the United Nations General Assembly, to estimate how states and groups of states have changed their foreign policy alignment to be closer to or farther away from China during the period that began in 1972 and ends quite recently, namely, in 2012. 
A key empirical finding that emerges from the analysis is that if we conceive of political alignment and re-alignment in terms of similarity of alliance portfolios, then during a period in which China has experienced a stunning rise in global power, many countries in Asia and around the world, with notable exceptions such as Pakistan and Russia, appear to be putting some distance between themselves and China, and may be moving to align themselves more closely to the United States. In addition, if we view alignment and re-alignment in terms of voting similarity at the United Nations, then we see fewer clear-cut efforts by countries to move either toward China or the United States. There is one notable exception to this general stability in UN voting affinities: most of the U.S. AsiaPacific allies seem by their UN voting to be generally moving away from China and closer to the United States, although they are differing in the extent to which they are changing their UN voting in ways that are interesting and invite fuller analysis.

The central motivation for this paper, and the main contribution it seeks to make, is to identify patterns of alignment and re-alignment by states in response to growing Chinese power. We seek to determine in particular whether states are adjusting their foreign policies to move closer to or farther away from China. The initial conclusion we offer is that numerous countries seem to be taking the first steps to balance against that country as it rises in power. However, we emphasize that it too early to know whether we might be seeing the same kind of polarization of alliances and political alignments that made cooperation progressively more difficult and conflict correspondingly more likely in the years prior to World War I, and that characterized the hard years of the Cold War, or whether a more fluid diplomatic situation characterizes the contemporary era, perhaps in part because the U.S. strategy of engagement specifically aims at socializing China (Johnston 2000) to be a moderate force in world politics notwithstanding its rise in power.

\section{POWER SHIFTS AND INTERNATIONAL ALIGNMENTS: IR THEORY AND EMPIRICAL EXPECTATIONS}

If we turn to international relations theory as a possible guide for expectations about whether we ought to expect foreign-policy realignments by countries in the Asia-Pacific and around the world in the face of rising Chinese power, our first candidate for such guidance is obviously the power-politics or realist tradition. The discussion below will therefore focus on the different strands of thinking within that tradition about shifting alignments, or even balancing, by states 
in the face of a rising power. We will find that while those different strands do expect the states of the Asia-Pacific to be making adjustments to rising Chinese power, not all expect those states to be moving in the same direction toward or away from China.

At the same time, realist theories and closely-related arguments are not the only perspectives that we can utilize in developing expectations about how countries in the Asia-Pacific and around the world are likely to be reacting to growing Chinese power. As we will see below, scholars in recent years have suggested that the domestic political institutions of a state, and in particular whether it is democratic or not, may play a material role in its orientation toward and capacity to engage in cooperation of any sort with other countries. We can deploy that line of research about the general capacity of democratic states to cooperate to derive the expectation that whether or not countries are realigning their policies in reaction to China's growing power may depend on whether they are able to coordinate on some form of reaction.

At the heart of the power-politics perspective in international relations is the thesis that a state that gains in material power will, at some point, induce other states to coalesce in a countervailing coalition. That coalition will either check the rising power's ambitions short of war, or if war comes the members of the coalition will work together to defeat the rising state and thereby retain their sovereign independence and security in the international system.

The distinguishing feature of what might be called the capabilities-balancing thesis is that states define, after some point, increases in the material capabilities of a rising power as constituting a danger to which they must individually and collectively respond. Kenneth Waltz put forward the most systematic statement of this thesis in recent times in his seminal work, Theory of International Politics. In that work, Waltz seeks to understand how the objectives and behavior of states are shaped by their co-location within an anarchical political structure, and by their possession, at a minimum, of a preference to survive as independent actors. What emerges is what he terms a "balance-of-power" theory, and he says that "If there is any distinctively political theory of international politics, balance-of-power theory is it" (Waltz 1979, 117).

At the core of Waltz's balance of power theory is the argument that states that possess a preference to survive will find it useful and necessary in the face of a rising state, defined as one that is growing in material capabilities, to take steps to ensure and promote their security through a combination of two policies. The first policy option is internal balancing: for example, in the face of a rising challenger other states may seek to build up their national capabilities through increased defense spending, support for economic growth, and investments in 
scientific development. The second strategy is external balancing: states in reply to a rising challenger will form coalitions with other states that are directed against the rising state.

Waltz does not say that states so facing a rising power will automatically or seamlessly react with one or another form of balancing, or some combination of the two. However, he does emphasize that, in contrast to domestic politics, where individuals often "bandwagon" toward the person who seems to be likely to win an election or otherwise attain positions of authority, "Externally, states work harder to increase their own strength, or they combine with others, if they are falling behind" (Waltz 1979, 126). He argues further that, if two competing coalitions are forming in world politics, "If states wished to maximize power, they would join the stronger side, and we would see not balances forming but a world hegemony formed. This does not happen because balancing, not bandwagoning, is the behavior induced by the system" (Waltz 1979, 127).

Waltz's balancing thesis has been enormously influential and controversial in the field of international relations. ${ }^{2}$ Among the unanswered questions that emerge from his line of inquiry is this particular issue: what is the mechanism by which the augmentation by one state, or a coalition, instigates fear in other states and induces them to work individually and jointly to check the rising state or coalition? How, in other words, do states know that they need to balance as one among them rises in power?

One reply might be that a rising power constitutes by its very existence a threat to others, and the others respond accordingly. In other words, balancing may be the result simply of the possession of prudence on the part of the other states. Prudence, however, is a hard concept to measure, and it is often manifestly missing in states.

However, A.F.K. Organski's "power-transition thesis" proposes a mechanism by which a state that is growing in material capabilities may come to act in ways that instill fear in and counteractions by others. Organski argues that as a state grows in power, as Germany did, for example, in the decades before World War I, it may come to believe that its ability to enjoy the fruits of that growing power, and, in particular, its ability to improve its share of the division of whatever is of value to the nations of the world, and its ability to shape the rules and norms of the existing international order, are constrained by the order that had been founded by the then-reigning hegemonic state and its nearest associates. This juxtaposition of rising material power and a perception that it is being denied

\footnotetext{
${ }^{2}$ Perhaps the most compelling critique of Waltz's balancing thesis is presented by Vasquez (1997); for responses to him see Waltz (1997), Walt (1997), Schweller (1997), and Elman and Elman (1997).
} 
the opportunity to translate that power into influence and the gains from such influence causes the rising power to become dissatisfied. As Organski put the thesis, "A rapid rise in power thus produces dissatisfaction in itself" (Organski 1958, 328). It is this dissatisfaction that motivates the rising power to take concrete actions to wrestle away world leadership from the reigning power and its allies. The existing leading state eventually replies with a strategy aimed at maintaining its status as the system leader, and among the actions it might take is to organize supporting secondary states in a counter-challenger coalition. In the end, the prospects for war, according to Organski, are distressing high. ${ }^{3}$

Thus, strictly on the basis of changing balances of material power, the Waltzian balance-of-power theory, buttressed perhaps by Organski's powertransition theory, we can expect that a rise in Chinese power will cause other states gradually to move away from China and toward the current status quo power, the United States.

Waltz's theory of balancing solely as a result of changes in relative power has prompted important and useful scholarly debates. One of the most important lines of criticism concerns the post-World War II alignment of states. Even though the United States in the years immediately after World War II was far and away the most powerful state in the international system, Japan and a number of key states in Western Europe, most notably Germany, did not balance with the next-most powerful state, the Soviet Union, but instead allied with the United States. This alignment pattern is very hard to explain using a strict balance-of-power approach. In reply, Stephen Walt (1987) put forward the "balanceof-threat" hypothesis, namely, that states balance against what they consider to be their most dangerous challenger. The identification of that challenger results from a weighting by states of a vector of factors, including material power but also geography and the revealed intentions of potential challengers. Hence, Japan and the Western European states balanced with the United States and against the Soviet Union because the latter was the greater relative threat.

Although Walt intended for his balance-of-threat thesis to underpin and reinforce Waltz's balance-of-power/capabilities argument, the two lines of analysis seem actually to pull in different directions (Vasquez 1997), and Waltz himself seemed to wish to put distance between his approach and Walt's amendment to balancing theory (Waltz 1997). For our purposes, we can imagine that countries that are relatively closer to China, and especially those that have had recent con-

\footnotetext{
${ }^{3}$ Organski developed his ideas on power transitions and war with Jacek Kugler (1980); additional key works in this line of inquiry include Lemke and Werner (1996), Kim (2002), and Bussmann and Oneal (2007).
} 
flicts of interest with China, will be especially likely to align their foreign policies more closely with the United States. For example, in light of disputes between Vietnam and the Philippines over islands in the South China Sea for a decade or more, and with Japan in respect the East China Sea, we might expect these countries to be especially likely to move their foreign policies away from China and toward the United States, both because the former is becoming more powerful and because they are experiencing more immediate threats from China than they are from the United States.

Finally, there is one final line of analysis that is generally within the balancing perspective that would lead us to expect that states would be likely to balance against China as that country has been growing in power. Jack Levy and William Thompson (2010) have suggested that the geographic position of rising states may influence the degree to which they become especially aggressive and therefore threatening to others. In a nutshell, they argue that maritime states that rely on trade for national well-being and seaborne power to project influence are less likely to conquer other countries, while continental states that become progressively more powerful may rely on and benefit from actual conquest, and thus are radically more dangerous to neighbors. Hence, in light of the fact that China still is and is likely to remain a continental power, and the United States, according to Levy and Thompson, is a major example of a maritime power, we can expect that in light of China's growing power, its immediate neighbors would be more likely to move away from China and closer to the United States.

In sum, different balancing theories - on the one hand, the Waltzian purecapabilities model itself, that model augmented by Organski's thesis about power and state satisfaction; on the other hand, Walt's balance-of-threat perspective, perhaps augmented by the Levy and Thompson thesis about maritime versus continental powers would seem to press us toward the following two expectations. First, in general, states are likely to be responding to growing Chinese relative power with a shift in their foreign policy alignments away from China and toward the United States. Second, countries that are experiencing conflicts of interests with China, such as Philippines, Vietnam, Indonesia, and Japan, are especially likely to be responding to growing Chinese relative power with a political movement from China and toward the United States.

Yet, according to other arguments in international relations, balancing is not necessarily what we can expect to see in the face of rising Chinese power. Paul Schroeder (1994) and Randall Schweller (1998) have suggested that states may react to a rising power with strategies very different from balancing. Schroeder, whose field of specialization was European diplomatic history, suggested, in reply to the Waltzian thesis that states react to rising powers by way of internal 
or external balancing, that "I cannot construct a history of the European states system from 1648 to 1945 based on the generalization that most unit actors within that system responded to crucial threats to their security and independence by resorting to self-help" (Schroeder 1994, 117). Schroeder argued that states, instead of displaying a consistent tendency to choose balancing in the presence of newly powerful states, often replied with bandwagoning, that is, joining the rising power against the current status quo major state. Opportunistic bandwagoning with Nazi Germany, Randall Schweller demonstrates, was in fact the policy of Fascist Italy and Imperial Japan at the outset of World War II. Hence, as China rises in power, we might see political movement by states away from the United States and toward China.

But bandwagoning is not the only option available to states in the face of a rising power. Another, more rare reaction, according to Schroeder, is "transcending," by which Schroeder meant seeking to act as an intermediary between the major contesting states. More often, Schroeder suggested, secondary states, when observing a growing contest between status quo and rising powers, have turned to a strategy he termed "hiding," that is, they have responded by "simply ignoring the threat or declaring neutrality in a general crisis, possibly approaching other states on one or both sides of a quarrel to get them to guarantee one's safety; trying to withdraw into isolation; assuming a purely defensive position in the hope that the storm would blow over; or, usually as a later or last resort, seeking protection from some other power or powers in exchange for diplomatic services, friendship, or non-military support, without joining that power or powers as an ally or committing itself to any use of force on its part" (Schroeder 1994, 117). Hence, it is quite possible that as China rises in power and challenges the United States for regional or global political primacy, the modal state response has been neutralism by most states, and especially by those in proximity to China.

To this point we have focused on how states might react to growing Chinese power as a function of those countries' own relative power. We have paid no attention paid to how those reactions might depend on the domestic political institutions either in China or in the countries that are finding it necessary to devise a response to Chinese power. This focus on China and the states that may be reacting to it as though they are unitary-rational "billiard ball" actors whose behavior is driven solely by their relative size and position is in keeping with the Waltzian view that internal conditions have a secondary role at best in shaping balancing outcomes in world politics. However, as noted at the outset of this section there is a new literature that suggests that how countries will respond to external threats and opportunities, including whether and how effectively they 
will work with other countries, depends vitally on their domestic institutions.

For example, Ajin Choi (2003; 2004) has found that a major reason for the greater propensity for democratic states to win the wars in which they become engaged is that they are better military allies. Choi in particular finds through both quantitative and qualitative analyses of war performance during major wars that democratic participants attract more allies, and in particular other democratic allies, than do non-democratic states; democratic states are better at coordinating with their allies on intra-war military strategy than are nondemocratic war fighters; and democratic states are less likely to abandon their allies in the midst of war. All of these features of democratic war-time coordination with and commitment to allies appear to combine to produce a higher probability of achieving victory for democratic states. In the same vein, Lisa Martin (2000) has found that, in general, democratic states, by virtue of the shared responsibility between their respective executive and legislative branches in the making of foreign commitments, are better suited to the construction of and subsequent adherence to international agreements. Moreover, Edward Mansfield, Helen Milner, and Peter Rosendorff (2002) have found that, controlling for a variety of purely economic conditions, democratic states are more efficient in crafting trade liberalization agreements with each other, and this allows them to foster higher trade flows among themselves rather compared to what we observe between democratic and non-democratic states, or among pairs of non-democratic countries.

If this line of analysis regarding democratic international coordination is correct, then if we do see some balancing in recent years against China and toward the United States as China has risen in power, then the countries that we should be most likely to observe doing so will be the countries that are as firmly democratic as the United States.

\section{TRACKING CHANGES IN RELATIVE POWER AND STATE ALIGNMENTS: ANALYSIS OF PRE-WORLD WAR I EUROPE}

Our central goal is to ascertain whether countries have been shifting their foreign policies to be more closely aligned to United States or China as the latter has been rising in power. We will proceed toward this goal in three steps. First, we need to determine if we in the field of international relations are in possession of a valid measurement strategy for estimating shifts both in inter-state relative power and in political alignments between and among those states. We suggest below that such a measurement strategy may indeed be available. To measure shifts in relative 
power, we have the Correlates of War's Composite Index of National Capabilities (CINC). On one the matter of measuring shifts in inter-state political alignments we have at least two measures: S-scores, developed by Signorino and Ritter (1999), which seek to measure how closely the alliance portfolios of any two countries are in given year, and a comparable measure of the similarity of voting in a given year by any two countries in the United Nations General Assembly, which was developed by Erik Gartzke (2006) and extended by Strezhnev and Voeten (2013).

In the analysis below, national CINC scores and S-scores for the pre-World War I period were accessed with the Eugene Data Management Program (Bennett and Stam (2008). As noted in the introduction, the current Eugene program reports S-scores only up to 2000. The Correlates of War data project has recently made available data on inter-state alliances up to the year 2012. That data on alliances, together with CINC scores up to the final year for which they are available from the Correlates of War, namely 2007, were employed to calculate global-capabilities weighted S-scores for the period, 1972-2007.4 UN voting affinity scores were downloaded from the Harvard Dataverse Network (Strezhnev and Voeten 2013).

How do we know that these measures reflect in a meaningful way the concepts that we are trying to capture, namely, power and shifts in alignment? We take up that question in this section. We seek to determine whether CINC scores capture an earlier major shift in power, namely, that between Britain and Germany during the last quarter of the $19^{\text {th }}$ century and the first decade of the $20^{\text {th }}$ century, and whether S-scores changed in ways that have been emphasized in historical narratives about the origins of World War, namely, a bipolarization of European alliances. This procedure will allow us to gain some insight into whether relevant countries changed their alliance patterns as Germany rose in power. We do not have a comparable test about the utility of UN voting affinity, which is one more reason to be cautious about any inferences that we might draw about any changes, or lack of changes, that we see in that voting as China has become a more powerful state in the international system.

How do we know that one state is rising in comparison to other states, including the most powerful states in its region and in the international system? Here we turn to the CINC measure. Annual CINC scores for each country are based on six components of what are thought to be bases of national power: total population, total urban population, iron and steel production, energy consumption, military personnel, and military expenditures. The CINC score for a given country in a given year is calculated by taking the sum of the averages of a country's respec-

${ }^{4}$ I thank Giacomo Chiozza for calculating and sharing these S-scores. 
tive shares of the global amounts of each of the six components.

For political alignment, and shifts in political alignment, we analyze S-scores. In general, S-scores between any two countries can vary from -1.0 (the two states have exactly the opposite portfolios of allies) to 1.0 (the two states have identical alliance portfolios). There are multiple variants of $\mathrm{S}$, based on whether regional or global capabilities (measured by CINC) are included in the calculations of the rank-order correlations of alliances between any two states. Since countries are probably very interested in the capabilities of their allies, utilized below is the variant of $S$ that includes in the estimation of similarity of alliance portfolios a weighting based on global shares of capabilities of partners. Signorino and Ritter indicate that weighted versions of S provide better estimates of what the measure is seeking to capture about real-world international politics, namely, the similarity of alliances between any two countries $(1999,133)$.

Are CINC and S-scores able to capture changes in national power and shifts in inter-state political alignments? We need to be able to answer this question in the affirmative if we are going to employ them to good effect (and, in a related vein, UN affinity scores) in an attempt to determine if states are moving closer to or farther away from China as that country has been growing in power. One way to test for the capacity of CINC and S-scores to shed light on today's international politics is to employ them in an examination of both trends in power and alignment prior to World War I. We can in particular examine two features of the years prior to 1914 that historians emphasize as contributing to the onset of World War I: first, the rise of German power relative to other states, and in particular the United Kingdom, Russia, and France, which created tension with those countries (Clark 2013; Macmillan 2013); and second, that in response to rising German power the European states split into two camps, the Triple Alliance of Germany, Austria-Hungary, and Italy, and the Triple Entente powers of Britain, France, and Russia. If we find that German power was increasing relative to its neighbors prior to 1914, and if we find that alliance ties subsequently moved in the direction of the formation of the two blocs, then this would suggest that S and CINC can capture the kinds of perceptions about power and actual diplomatic developments that are emphasized in historical narratives about the pre-WWI era.

What then can we say about shifts in power and in alliance alignments prior to World War I? Power shifts during this period are reported in Figure 1: it presents the CINC scores of the major European states and the United States between 1874 and 1914 .

At least two observations can be made about the trends in relative power depicted in the figure. First, the initial major change in relative global power did not involve Germany: instead, it consisted of the United States surpassing Britain in 
Figure 1. Shares of Global Capabilities: European Major Powers and the United States, 1874-1913

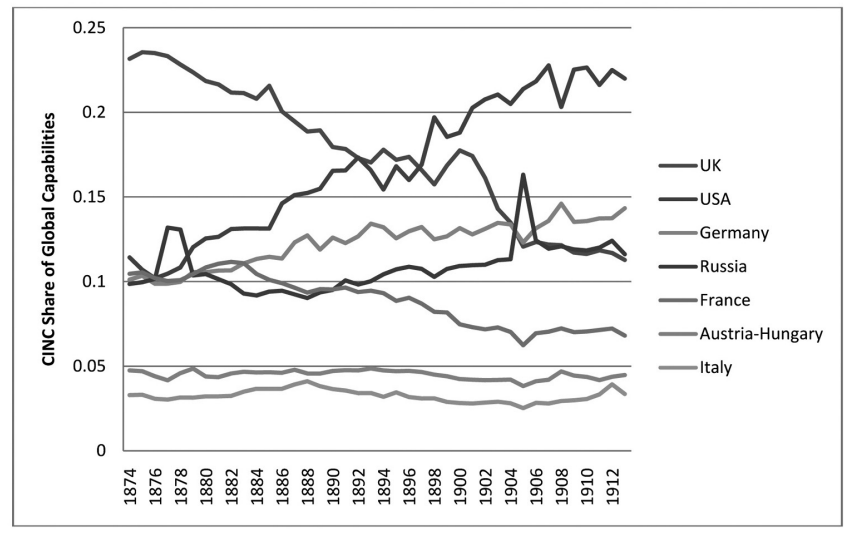

Source: Eugene data program (Bennett and Stam 2008)

overall capabilities over the course of the early-to-mid-189os, and decisively so by no later than 1900. This shift in relative power of course presents a major puzzle to power-transition theory, as Organski (1958, 323-325) recognized and sought to explain. We should keep the U.S.-Britain experience constantly in mind when we talk about contemporary power trends in the Asia-Pacific. That experience underscores the point that while power transitions may be sufficient to generate tensions between the rising power and other states, including the current leading state (they did in the U.S.-Britain case to a moderate degree and to a much higher degree prior to World War I), they are not sufficient to bring about major power conflicts or wars between the contesting states.

Second, by utilizing CINC scores we are able to capture the rise of Germany. That country possessed shares of total global capabilities that were roughly comparable to those of Russia, France, and the United States during the period roughly between 1874 and 1884, with Britain enjoying during that period a comfortable margin in capabilities over all those countries. The United States exploded in capabilities and caught up and surpassed Britain. Germany also, but at a much slower, more steady pace, also grew in terms of relative power, and finally surpassed Britain by a slight margin during the early years of the 1900s, and was clearly ahead of Britain in relative power by 1907 or 1908.

It is precisely during this period that the two European alliance blocs were being formed or fortified. The Triple alliance has been established first, in the 1880s. During the 1890 s and early 1900 s the ties between Austria-Hungary and Germany became progressively more important to each other (each discounted Italy's role in the Triple Alliance). More important for our purposes is the rise of 
the Triple Entente, which consisted of the Anglo-French Entente Cordiale of 1904, and the Anglo-Russian Entente of 1907. These two realignments, plus the earlier Franco-German military alliance of 1894, marked a significant re-alignment and then freezing of political ties in Europe prior to World War I.

The key question for the moment is whether trends in alliance portfolios as measured by S-scores more or less reflect this polarization of European interstate relations at the end of the 1890 os and the beginning of the 1900s. We can address that question by reference to the two panels in Figure 2 .

Panel A focuses on the level of similarity between the alliance portfolios of the European great powers and the alliance portfolio of the United Kingdom from the 1870 s up to the eve of World War I. We can see in the panel that, from the $1870 \mathrm{~s}$

Figure 2. Alliance Portfolios and Shifting European Alignments, 1874-1913

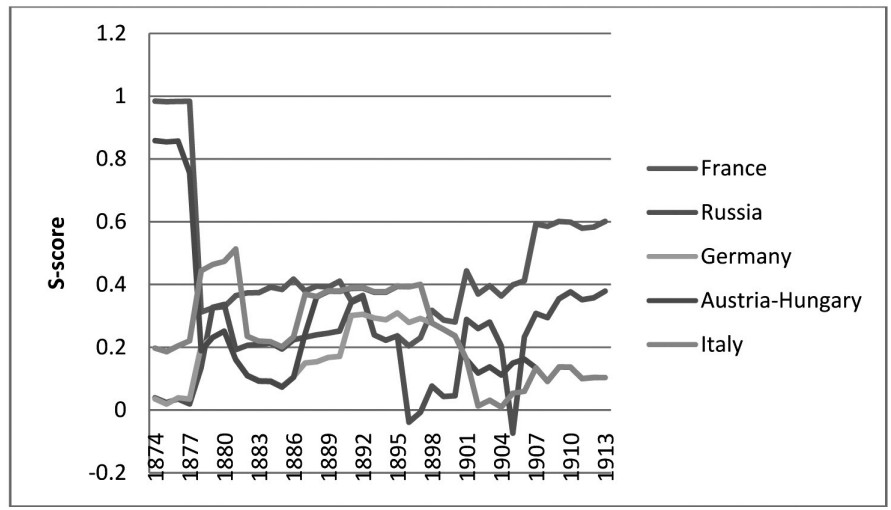

Panel A: Similarity of Alliance Portfolios: Major European States and Britain

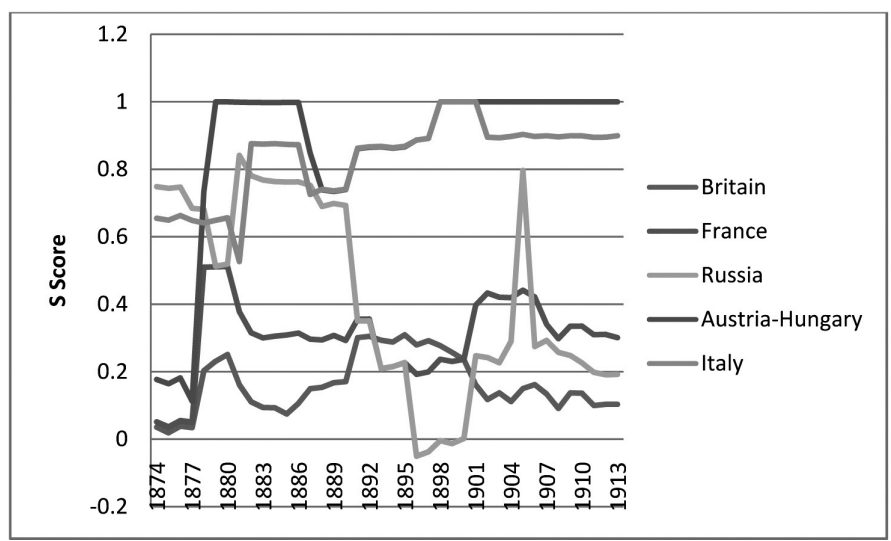

Panel B: Similarity of Alliance Portfolios: Major European States and Germany 
to the mid-189os, there is a great deal of volatility in the S-scores of all the European countries vis-à-vis Britain. From the mid-189os onward we see a steady downward trend in S-scores comparing Britain's alliance portfolio to that of Germany, Austria-Hungary, and Italy, suggesting that these three countries pulled away from Britain in terms of the diplomacy of alliance formation during the years prior to World War I. In contrast, during the first few years of the 1900 , and most clearly between 1904 and 1907, the alliance portfolios of France and Russia begin to converge with that of the United Kingdom.

Panel B depicts the same polarization of alliance structures, but from the viewpoint of the alliances portfolios of European great powers when compared to Germany's network of alliances. As we can see in the upper part of Panel B, Austria-Hungary and Italy in the 1880 os became closely aligned to Germany in terms of having similar alliance portfolios with that country (for example, establishing formal alliances with each other and with Germany and not doing so with France, Britain, or Russia), and that alignment pattern remained constant right up to the eve of World War I. More interesting are the S-scores of Britain, France, and Russia with respect to Germany. Prior to the early 1900s, there were marked fluctuations in alliance S-scores of Britain, France, and especially Russia vis-à-vis Germany, suggesting substantial fluidity in the alliances during that period. However, notice that in the early 1900s, and especially from 1904 onward, the Sscores of Britain, France, and Russia with regard to Germany dropped at relatively similar rates, suggesting that their alliance portfolios were moving in tandem away from Germany's portfolio. That is precisely the pattern in S-scores that we would expect to see given the actual diplomatic history of the period: from the early 1900 , and especially from 1904 onward, Britain, France and Russia coalesced and moved toward each other and in opposition to Germany.

Hence, CINC scores seem to capture changes in relative power among countries over time. Alliance S-scores in turn appear to shed light on actual alliance portfolios and the more general alignment of countries, and, very importantly for our task of looking at the contemporary situation in the Asia-Pacific, S-scores seem to have some capacity to capture changes in the alignment patterns. Hence, as a first cut into an analysis of whether we are observing balancing, bandwagoning, or some other form of re-alignment of foreign policies in the Asia-Pacific and around the world in response to China's rise in power, it would seem reasonable to use CINC data to try to capture the possible shift in power by China, and Sscores or comparable indices to see if and to what degree different countries are shifting their political allegiances in response to that shift in power. 


\section{CHINA'S RISE IN POWER AND POLITICAL ALIGNMENTS IN THE ASIA PACIFIC, 1972-2012}

We may now turn to an analysis of shifts in global power in the contemporary era and their consequences for alignment patterns, if any, by states in the Asia-Pacific and by other countries. To begin, national-capability levels and shifts in relative power from 1972 to 2007, as measured by CINC scores, are presented in Figure 3. The year 1972 is selected because it was the first full year that the People's Republic of China sat as a permanent member of the UN Security Council and was the sole representative of China at the United Nations.

Figure 3. Shares of Global Capabilities: Main Asia-Pacific Countries, 1972-2007

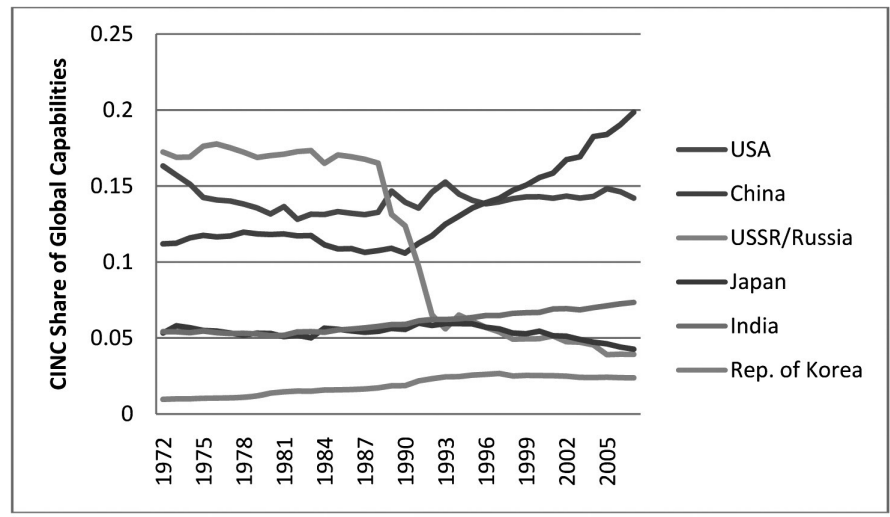

As can be observed in the figure, the Soviet Union at the outset of the 1970s was by a modest margin the world's pre-eminent state in terms of CINC shares, followed quite closely by the United States and China in turn not far behind in the third position in the hierarchy of international power. Indeed, given how tightly packed those three countries were during the 1970s and much of the 1980s, and the centrality of each state's foreign policy to the others, it is fair to suggest that by the early 1970 s the world had transitioned from a bipolar to a tripolar international structure of power.

In any event, we can see in Figure 3 the earthquake in world politics that occurred in the late-1980s and the outset of the 1990s. The Soviet Union collapsed, and its direct successor, Russia, dropped in relative power such that while the USSR possessed about $16 \%$ of the globe's total capabilities in 1988-89, Russia possessed about 6\% of such capabilities in 1993 and less than 5\% by the mid200os. The U.S. share of global capabilities remained notably similar in the post- 
Cold War period compared to what its share had been during the 1970 and 1980 . As can be seen in the figure, the U.S. share of global CINC capabilities stayed in a tight band from about a low of around $13 \%$ in 1982 to a post-Cold War high of $15 \%$ in 1993, and ended the period under review with a CINC share of roughly $15 \%$. In contrast, China's share of global capabilities exploded in the wake of the Cold War, going from 10.6\% share of global capabilities in 1990 to almost $20 \%$ in 2007. It may also be noted in the figure that India has slowly risen in its share of global capabilities since the end of the Cold War, suggesting that its economic reforms of 1991 are beginning to translate into sustained economic development, although in relative terms that gap between it and China has been widening, to China's advantage, since the early 1990s; Korea seemed to gaining in global world power during the 1990s, but has been fading a bit since 2000; and Japan appears to be tracking Russia in terms of losing relative ground in the global distribution of capabilities.

Finally, notice that if we give CINC scores a reasonable level of credence as an indicator of national power and changes in relative power, China actually surpassed the United States in relative power in the mid-1990s. Many if not most observers of world politics would likely take issue with this characterization, and would cite shortcomings of the CINC measuring system such as its failure to take into account directly such elements of power as overall technological sophistication or military technology and efficiency. Still, even if Chinese relative power is not rising at quite the same rate as is reflected in the figure, it seems reasonably clear that China has been rising in relative power (for example, in terms of the overall size of its economy), and may soon match the United States, if it has not already done so, in terms of many elements of power.

If it is true that China is approaching (or even perhaps has matched or exceeded) the United States in overall power, it is also true that we haven't seen a war or even intense political-military conflict between those two countries, although recent developments in the East China Sea highlight the potential for trouble between the two countries. Hence, just as with the transition between the United States and Britain in the mid-1890s and between Germany and Britain in the early 1990 s, so to power transition that has occurred or must surely be underway between China and the United States in recent years has not prompted to date a major war over hegemonic leadership of the international system. Moreover, we cannot yet say if the power transition will end as did the Anglo-American transition (no war) or the Anglo-German experience (war).

Can we observe changes in the alignment of countries toward or away from China or the United States in the face of the power transition between those two countries? To address this question, we will return once more to S-scores regard- 
ing the similarity of alliance portfolios.

Before we turn to our analysis of changes by countries in their political alignment with China and the United States using those two indicators, we need to ask, which countries should we examine in respect to such alignment choices? For this initial study, we focus on a sample of forty countries listed in Table 1. The sample includes eight countries that are important U.S. allies in the Asia-Pacific region; four important member countries of the Association of South East Asian Nations (ASEAN); four of China's partners in the so-called BRICS grouping of emerging economies; and finally, a control group of 24 countries randomly drawn from the Correlates of War list of members of the state system.

Table 1. Country Groups for Analysis of S and UN Voting Affinity

\begin{tabular}{|c|c|c|c|}
\hline U.S. Asia-Pacific Allies & ASEAN Countries & BRICS except China & Control Group \\
\hline Australia & Indonesia & Brazil & Argentina \\
\hline Canada & Malaysia & India & Bahrain \\
\hline Japan & Singapore & Russia & Dominican Rep \\
\hline New Zealand & Vietnam & South Africa & El Salvador \\
\hline Republic of Korea & & & Eritrea \\
\hline Philippines & & & France \\
\hline Pakistan & & & Georgia \\
\hline \multirow[t]{17}{*}{ Thailand } & & & Greece \\
\hline & & & Guinea \\
\hline & & & Iceland \\
\hline & & & Iran \\
\hline & & & Israel \\
\hline & & & Italy \\
\hline & & & Laos \\
\hline & & & Maldives \\
\hline & & & Malta \\
\hline & & & Myanmar \\
\hline & & & Netherlands \\
\hline & & & Nicaragua \\
\hline & & & Peru \\
\hline & & & Samoa \\
\hline & & & Spain \\
\hline & & & St. Lucia \\
\hline & & & Swaziland \\
\hline
\end{tabular}


In general, we might expect the U.S. allies to be the most likely to be fortifying their alignment with the United States, while China's BRICS partners might be expected to be bandwagoning toward that country. The ASEAN countries are likely to have highly mixed interests: Indonesia and Vietnam, for example, have had serious disputes with China stretching back more than a decade over competing claims to the South China Seas, while Singapore and Malaysia have booming commercial ties with China. The control group, which includes countries from the Americas, Europe, Africa, the Middle East, and South East Asia, will serve as a point of comparison for the countries in the four groups of states that for one reason or another might be especially likely to be adjusting their political and military alignments in response to growing Chinese power.

We begin with trends between 1972 and 2007 in the level of similarity in alliance portfolios, that is, S-scores weighted by global shares of capabilities, between the United States and its main Asia-Pacific allies, and between those countries and China. These trends are presented in Figure 4..$^{5}$ Panel A of the figure examines alignment patterns between 1972 and 2007 from the viewpoint of the United States, that is, the focus in on how similar or different the alliance portfolios of U.S. Asia-Pacific allies were during those years to the U.S. alliance portfolio, as well as the average S-score for the control group with respect to the United States. Panel B presents data on the similarity of the alliance portfolios of U.S. Asia-Pacific allies with China's own alliance portfolio during the same years, as well as the average $\mathrm{S}$-score for the control group with respect to China.

Looking at the data in Panel A, we can see that S-scores between the United States and its Asia-Pacific allies and the control group were largely stable during most of the 1980s. This was followed by a modest downward direction and then stabilization in S-scores during late-1980s and early 1990s, with the exception of Canada, whose S-scores with respect to the United States began to rise during those years. During the bulk of the first decade of the 200os, we can see a fairly uniform increase in S-scores for most of the U.S. allies with respect to the United States, with the notable exception of Pakistan.

Panel B contains information that is particularly germane to the central question of this paper, namely, are countries re-aligning their alliance policies to be more closely in tune with or in opposition to China's as that country rises in

\footnotetext{
${ }^{5}$ As noted at the outset of the essay, there are four variants of $S$ that are available in Eugene; these vary on whether the similarity score between a country and any other is weighted or not by their respective CINC capabilities, and if so if the weighting by the countries' respective regional or global capabilities. In this analysis, because power capabilities might be a key influence on alignment choices, the variant of the S-score that incorporates global capabilities is employed, that is, s_wt_glo, although similar patterns in alignment can be observed using the remaining three variants of $\mathrm{S}$.
} 
power? Here we see a pattern in S-scores that is quite different from what we saw in the case of S-scores linking U.S. allies to the United States. After a substantial increase in S-scores for these countries with respect to China during the 1970 s and 1980 s, beginning in the early 1990 s, S-scores linking U.S. Asia-Pacific allies and China began to decline and this separation between the alliance portfolios of those countries and that of China continued during the first half of the 2000s, again with the notable exception of Pakistan. In sum, with the exception of Pakistan, with which the United States has had a fraught relationship, most U.S. allies in the Asia-Pacific in recent years seem to be coalescing somewhat more

Figure 4. Similarities in Alliance Portfolios with the United States and China, U.S. Asia-Pacific Allies, 1972-2007

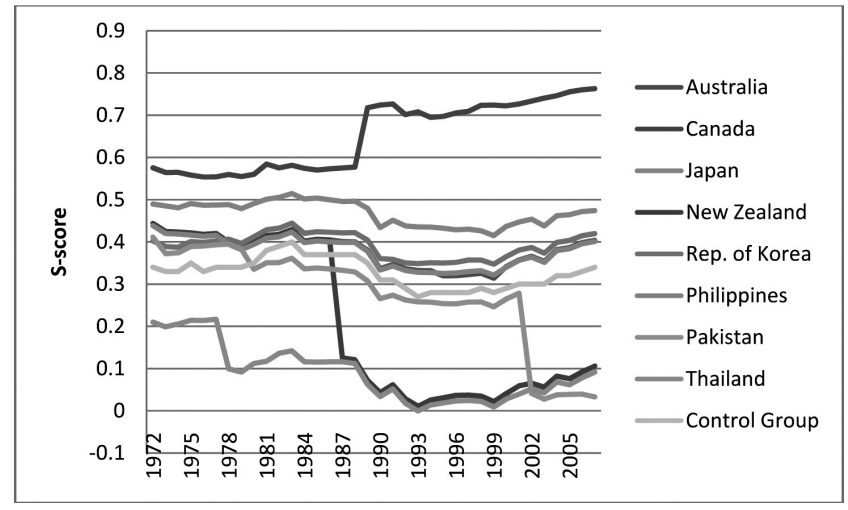

Panel A: Similarity of Alliances with USA

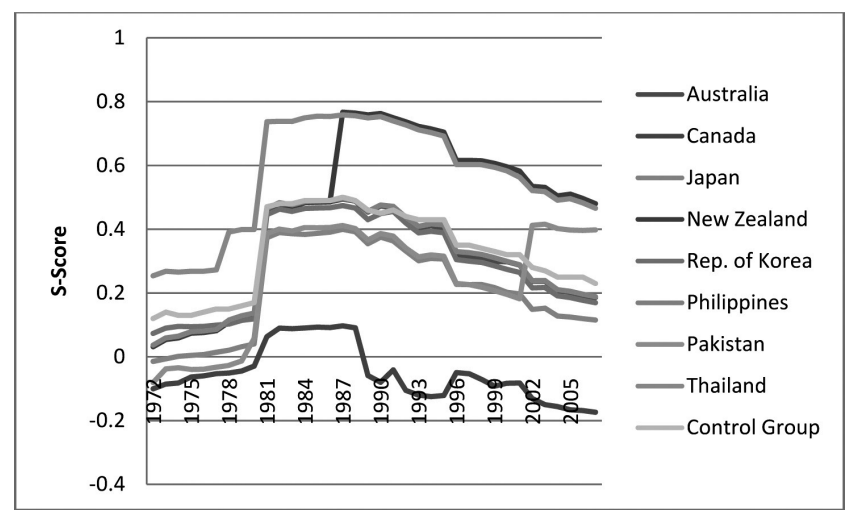

Panel B: Similarity of Alliances with China

Source: Correlates of War 
closely around the United States in terms of alliance portfolios, and they appear to be pulling away from China.

We can observe similar trends in S-scores that link the United States and China with four important ASEAN countries-Indonesia, Malaysia, Singapore, and Vietnam. This can be observed in Figure 5 .

In Panel A of the figure we present S-scores linking these countries and the United States. As can be observed in the panel, after a steady downward trend in S-scores between these countries and the United States from the 1970s into the

Figure 5. Similarities in Alliance Portfolios with the United States and China, ASEAN Countries, 1972-2007

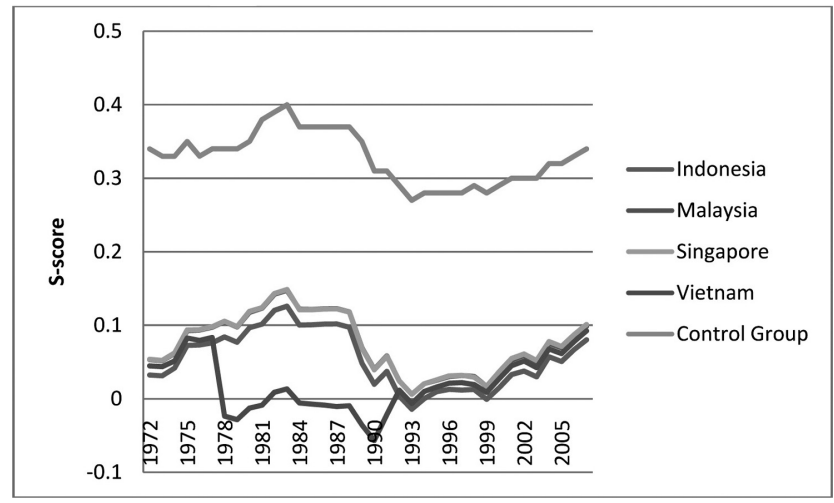

Panel A: Similarity of Alliances with USA

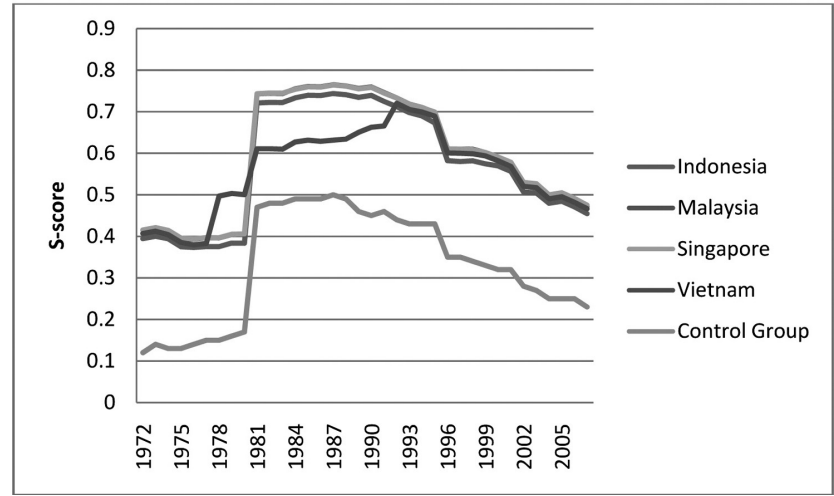

Panel B: Similarity of Alliances with China 
1980 , from the 1990 on onward these countries seemed to be moving closer to the United States in terms of alliance portfolios. In panel B, we see a pulling away by these countries from China in terms of S-scores. The direction of change in Sscores seems to be reasonably clear and consistent: the four ASEAN countries, in the face of rising Chinese power, appear to be aligning themselves to a modest degree from China and, at the margins, they are moving in the direction of the United States.

Finally, we might ask if China's cooperation on economic matters with partners in the BRICS grouping might also adjusting their alliance portfolios to be more in

Figure 6. Similarities in Alliance Portfolios with the United States and China, BRICS except China, 1972-2007

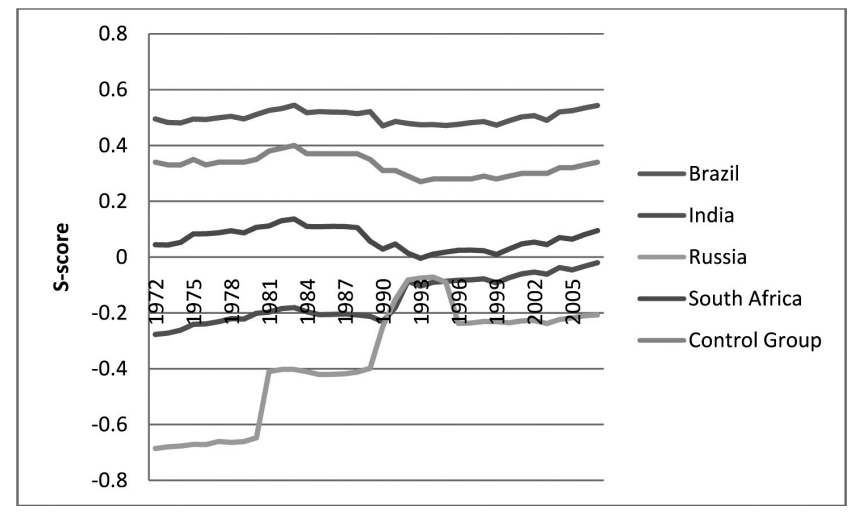

Panel A: Similarity of Alliances with USA

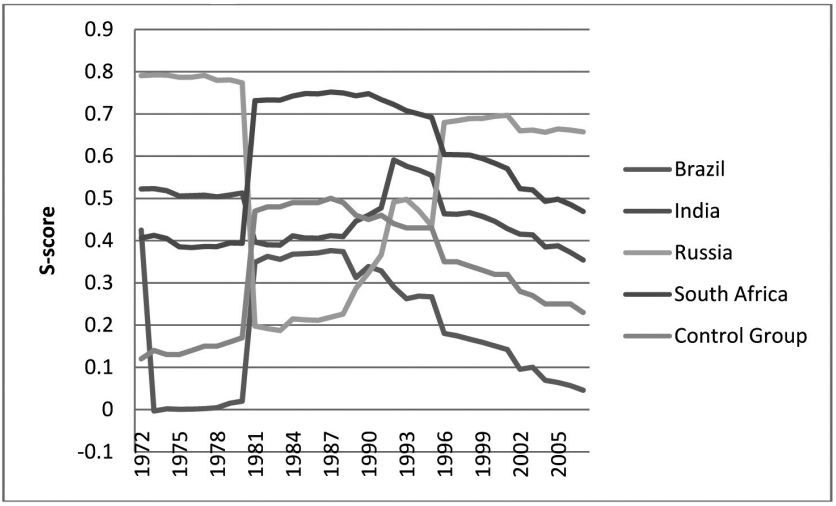

Panel B: Similarity of Alliances with China 
line with China's, while perhaps also becoming more distant from the United States: we take up that possibility with the data presented in Figure 6.

While we might expect the China's BRICS partners to be the most likely to move toward China and away from the United States, we actually see contrary trends, with one notable exception. Let us begin with the exception: Russia. In Panel A of the figure we can see that after moving relatively closer to the United States in terms of alliance portfolios in the immediate years after the end of the Cold War, from 1995 onward Russia's S-score with respect to the United States dropped and remained low through 2007. At the same time, we can see in Panel B that Russia's S-scores with regard to China dropped precipitously as those two countries became bitter rivals in the 1970 s and 1980 s, but with the end of the Cold War and into the early 1980 os Russia moved closer to China in terms of their respective alliances, and Russia and China's S-scores have remained relatively high and stable since the mid-1990s. In contrast, the other BRICS countries have moved ever so slightly more closely to the United States in terms of their alliance portfolios, and they have moved quite markedly away from China's mix of alliances. Very notable is the case of India: its S-scores with the United States began a modest upward trajectory beginning in the 1990s, while precisely during this period its S-scores with China commenced what to date has been a steady downward movement.

In sum, whether we look at S-scores of the United States and China with U.S. Asia-Pacific allies, a sample of important ASEAN countries, or China's BRICS partners, we see, with some notable exceptions, a generally modest movement during the past twenty years toward the United States in terms of similarly of alliance portfolios, and a more emphatic movement away from China. Taken as a whole, the countries in the control group follow a similar pattern: modest movement toward the United States, and a more clear-cut movement away from China. At a minimum, these patterns in similarities and differences in alliance portfolios would seem to suggest that many states in the Asia-Pacific, as well as a variety of other countries, with the exception of Pakistan and possibly Russia, are not bandwagoning toward China. Instead, the patterns are consistent with the view that many states may be putting some distance between themselves and China, and are seeking to align themselves somewhat more closely to the United States.

Our confidence in this initial characterization of how states have been reacting to the rise of China would be fortified if we saw similar trends in another, unrelated set of data that reflect on alignment and re-alignment in world politics. For that reason we turn to UN voting affinity scores, that is, the level of similarity between states in their voting at the UN General Assembly (UNGA). In this discussion below we examine UN voting affinity scores between the United States 
and China on the one hand, and the countries we discussed above on the other hand, between 1972, the first full year the People's Republic of China occupied China's chair at the UN, up until 2012 (Strezhnev and Voeten 2013). Annual UN affinity scores are based on an average of about 85 UNGA votes each year between 1972 and 2012. The calculation of UN affinity scores employs the same procedures developed by Cutter and Signorino to calculate alliance-portfolio S scores. By consequence, for any pair of countries, the annual UN voting affinity score can vary from -1 (the two countries voted on opposite sides on all UNGA resolutions) to +1 (the two voted the same on all UNGA resolutions).

Figure 7. UN Voting Affinity Scores for the United States and China: U.S. Asia-Pacific Allies, 1972-2012

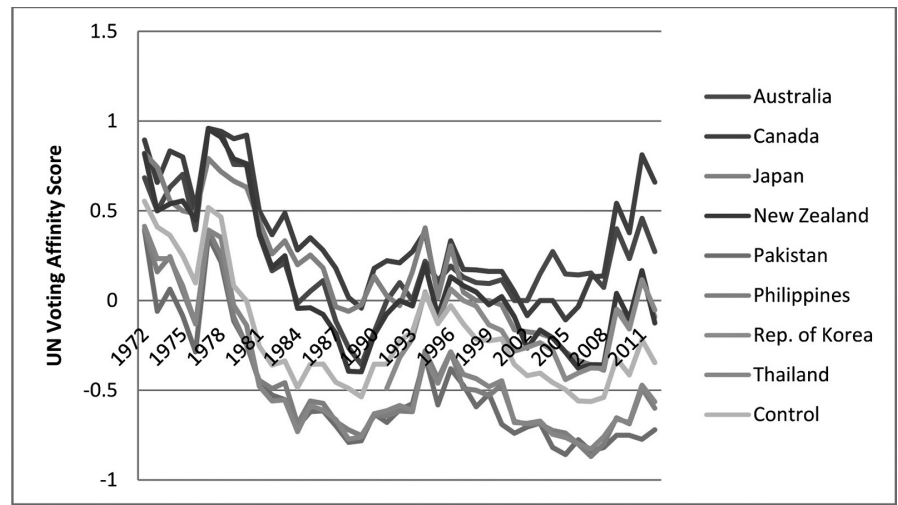

Panel A: UN Voting Affinity Scores: U.S. Asia-Pacific Allies and the United States

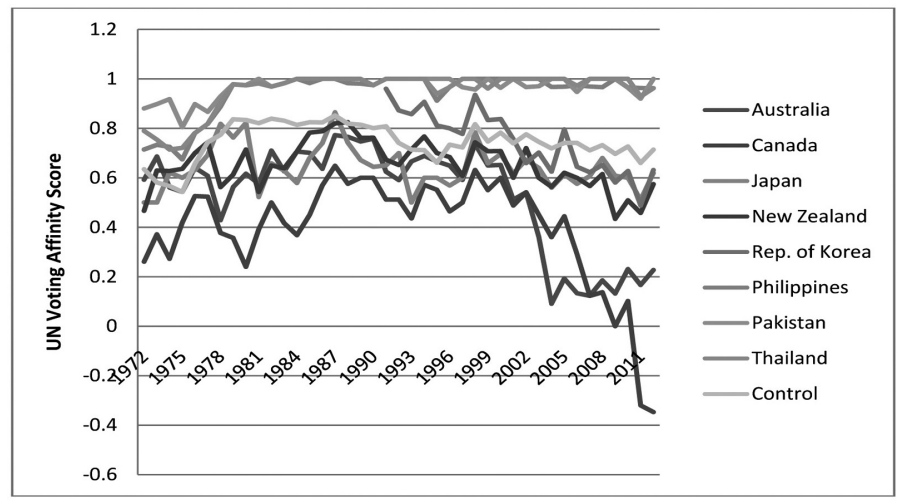

Panel B: UN Voting Affinity Scores: U.S. Asia-Pacific Allies and China

Source: Strezhnev and Voeten (2013) 
We begin with U.S. Asia-Pacific allies; their UN voting affinity scores with the United States between 1972 and 2012 are reported in Panel A of Figure 7, while their UN affinity scores with China during those years are reported in Panel B of the figure.

We can observe in Panel A that U.S. Asia-Pacific allies have varied a great deal among themselves in their UN voting affinity scores with the United States, and for a given U.S. ally there has been a great deal of variation across time. One notable characteristic of the trends captured in Panel A is that, looking at the entire time period, U.S. allies in the Asia-Pacific seem to increase their respective UN affinity scores with the United States during the administrations of presidents from the Democratic Party, and to reduce their affinity levels during Republican administrations. ${ }^{6}$ At the same time, it is notable that from 2005 onwards, that is, from even during the latter years of the administration of Republican George W. Bush, the UN affinity scores of most of U.S. allies began to move upward. Different countries did so from different initial levels and then at different upward rates, and we will return in a moment to identification of a possible pattern that requires attention to the domestic institutions of the different U.S. allies. At this point we can perhaps say that after a long, steady decline in UN affinity scores that began in the 1970 s and, with some ebbs and flows, continued through the 1990 s and the beginning of the 2000s, in the middle of that decade and into the first years of the present decade UN affinity scores between the United States and its Asia-Pacific allies suddenly and strongly turned upward.

Turning to UN voting affinity between U.S. Asia-Pacific allies and China, the data in Panel B of Figure 7 tell a much clearer story. Two of the allies, Thailand and Philippines, began to vote in almost exactly the same way as did China in the late-1970s, and they have never stopped doing so. The UN voting affinity scores of the other six U.S. allies followed a very different trajectory. For a number of years their affinity scores with China gradually rose, suggesting enhanced similarity in voting, and then, in the years 1998 to 2002, these scores simultaneously began to decline. The rate of decline differed across the six U.S. allies, and we will come back to that below. For the moment there would appear to be grounds to observe of Panel B that, with the exceptions of Thailand and the Philippines, U.S. Asia-Pacific allies generally became markedly more inclined to vote differently from Chinese UN voting as China became clearly more powerful from the late1990 s right up to the present.

When we turn to UN affinity scores for the four ASEAN countries with respect

\footnotetext{
${ }^{6}$ I thank Christopher Gelpi for identifying this characteristic of UN voting affinity scores by U.S. allies apparently tracking Republican and Democratic administrations in Washington.
} 
to the United States and China, presented in Figure 8, and for comparable scores involving the BRICS countries, presented in Figure 9, we see much less evidence of re-alignment by those countries in favor of either the United States or China. For example, as we can observe in Figure 8, while we see two substantial swings in most of the UN voting affinity scores of the four ASEAN countries with respect to the United States that appear to depend on whether the U.S. administration was headed by a Democrat or a Republican, the general trend over time has been for these countries to vote at the UN General Assembly not in accord with U.S. votes. At the same time, these countries have had extremely high voting affinity

Figure 8. UN Voting Affinity Scores for the United States and China: Selected ASEAN Countries, 1972-2012

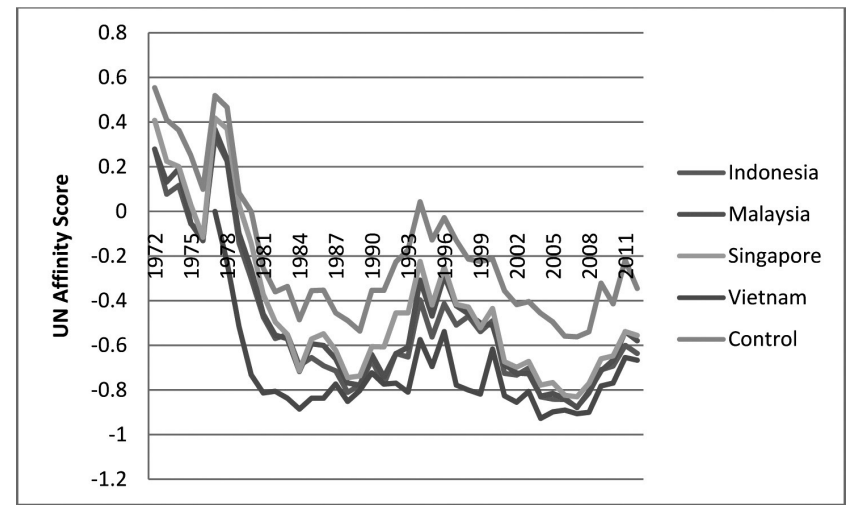

Panel A: UN Voting Affinity Scores: Selected ASEAN Countries and the United States

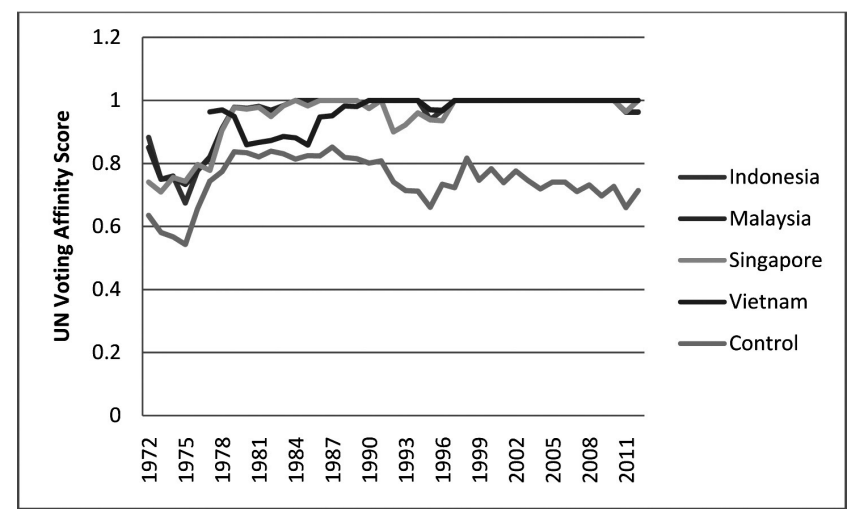

Panel B: UN Voting Affinity Scores: Selected ASEAN Countries and China 
Figure 9. UN Voting Affinity Scores for the United States and China: BRICS Countries except China, 1972-2012

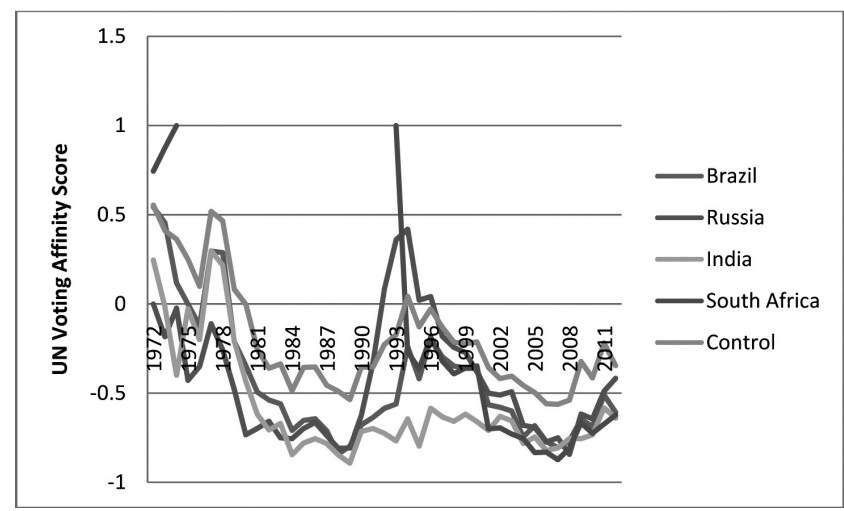

Panel A: UN Voting Affinity Scores: BRICS except China and the United States

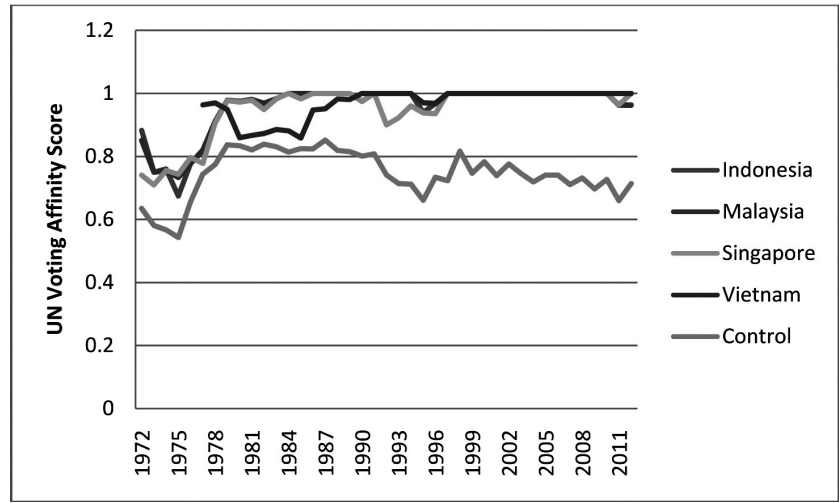

Panel B: UN Voting Affinity Scores: BRICS except China and China

Source: Strezhnev and Voeten (2013)

scores with respect to China since the late-1980s. Very similar observations can be made in regard to BRICS countries other than China: as can be observed in Figure 9, they are highly likely to vote the same way at the UN as China, and with some changes from year to year they vote differently from the votes cast by the United States.

Countries in general do not appear to be changing their voting patterns at the UN as China has surged ahead in material capabilities. The exception is that of U.S. Asia-Pacific allies: several of those allies do seem to pulling away from China to some degree. Hence, to the extent that UN voting is reflective of stances taken 
by states in world politics, there appears to be some evidence that U.S. Asia Pacific allies are reacting to rising Chinese power with a modest movement on their part away from China and a slightly more robust effort to align themselves with the United States.

Finally, we noted above that scholars have emphasized in recent years that the domestic institutions of countries, and in particular, whether they are democratic or not, influences their capacity to cooperate and align their policies in similar directions. We can examine that expectation by returning to the data in Figure 7 , which presents the UN affinity scores of each of the U.S. Asia-Pacific allies with the United States (Panel A) and China (Panel B) between 1972 and 2012.

We noted above that America's allies in the Asia-Pacific generally experienced increasing UN voting affinity scores with the United States and declining UN voting affinity scores with China from the mid-20oos to the end of our time series in 2012. It is possible that the replacement by the Republican administration of President George W. Bush by the Democratic administration of Barack Obama in 2009 accounts in part for the generally upward movement in UN voting affinity scores on the part of U.S. allies with the United States. However, it would not readily explain the variation in magnitude in the increases. We might be able to capture at least some of that variation by turning to the domestic-structures thesis about cooperation among democracies. If that thesis is correct, then we might reasonably expect that U.S. Asia-Pacific allies with highly mature (that is, deep, extensive, and of long duration) democratic institutions might be more tightly clustered together in their voting behavior with respect both to the United States and with China.

Patterns in voting affinity scores are somewhat supportive of the thesis. In Panel A of Figure 7 we see that, between roughly 2005 and 2008, and going to the end of our data series in 2012, Australia and especially Canada experienced very large increases in UN voting affinity with the United States, as did, from lower baselines, New Zealand, Japan, and South Korea. Thailand and Philippines, whose UN affinity scores with the United States steadily declined from the early 1970 s to the early 2000s, saw slight increases in their respective UN affinity scores with the United States between 2006 and 2012. Finally, Pakistan's UN voting affinity score with the United States steadily dropped from the 1970s to the mid-200os, and from that point increased only slightly up through 2012. Hence, it appears that, with the exception of New Zealand, the more mature the democratic institutions at home, the higher was the U.S. Asia-Pacific ally's baseline UN voting affinity with the United States throughout the period under review and, more important, the more emphatic the increase at the end of the period in the UN voting affinity score between the ally and the United States. 
We see similar patterns if we shift our attention to Panel B of Figure 7, and examine more closely UN affinity scores between U.S. Asia-Pacific allies and China. There we observe that, from the late-1990s to the end of the time series in 2012, Australia and especially Canada have had sustained and large drops in voting affinity with China; New Zealand, Japan, and South Korea are also moving in a markedly downward direction; and Thailand, the Philippines and Pakistan have not been changing their $\mathrm{UN}$ voting at the $\mathrm{UN}$ relative to Chinese votes. It would seem then, that a positive association exists between well-grounded democratic institutions at home and political realignment away from China by America's allies in the Asia-Pacific region. This association suggests that further analysis of alignment trends in the Asia-Pacific need to pay attention to the domestic structures of the countries that are likely to have to contend, in one way or another, with a rising China.

\section{CONCLUSION}

In this paper an attempt has been made to derive from international theory observable expectations about patterns of international alignment and re-alignment as China grows in power. In addition, an initial effort was made to employ readily available indicators of power, similarity of alliances, and of UN voting to determine if countries in East Asia and around the world are beginning to adjust their policies to be closer to or further away from China's alliances and UN policy preferences. This initial analysis suggests that states are reacting in different ways and degrees to growing Chinese power. U.S. Asia-Pacific allies, with the exception of Pakistan, are moving away from China and toward the United States both in terms of alliance portfolios and in terms of UN voting. Key ASEAN countries and countries that belong to the BRICS informal grouping, with the exception of Russia, seem to be moving to a moderate degree away from China in terms of their respective alliance portfolios. However, in UN voting what is notable are the high levels of similarity between China on the one hand and the four ASEAN countries and the BRICS on the other.

At least two theoretical inferences can be derived this analysis. First, states in general do not readily and smoothly change their policies, either to be more amicable or more confrontational, as power shifts occur around them. That is, the most straightforward capabilities-balancing thesis does not seem to providing strong empirical guidance for what we have been witnessing to date in the face of a rising China. On the other hand, several U.S. Asia-Pacific allies do seem to be adjusting their policies to be more distant from China both in regard to alliances 
and UN voting, and we may be seeing some movement away from China on the part of the four ASEAN countries at least in regard to alliance portfolios, but not UN voting. These developments, if confirmed by additional studies, would suggest that power shifts do in time, and in different degrees, have the capacity to induce shifts in alignment by relatively disadvantaged states, probably as a result of actual behaviors by the rising state that are associated with its rising power, and that domestic conditions in the reacting states may play a key role in affecting the tempo, level, and character of any re-alignments that they may undertake.

Caution is needed in drawing theoretical inferences from this analysis, and so too the greatest circumspection must be employed in deriving any policy implications from the discussion above. Still, given that discussion, at least one main policy-related point can be put forward for further reflection. In the face of growing Chinese power, while we may be seeing the first signs of balancing through adjustments in alliance portfolios by quite a few states both within the AsiaPacific region and beyond, the variability in UN voting suggests that we do not yet see today the kind of full-scope hardening and bipolarization of coalitions around China and the United States that we witnessed in the decade prior to World War I, when Europe became clearly divided into two mutually antagonistic blocs focused around Britain and Germany. There is, in other words, still a substantial fluidity in the diplomacy of East Asia and the Pacific. This gives diplomacy by the United States, its allies, and others time to ascertain if it is possible to navigate a path between appeasing China and seeking trouble with it, of continuing to search for ways to integrate it into the global order even as it grows in power.

Finally, at least three elements of a research agenda emerge from the analysis above. First, we need to identify additional indexes of alignment and re-alignment in the relationships of states. There are reasons to be skeptical about the degree to which S-scores and similarity levels in UN voting reflect major shifts in state alignments. That is, alliances tend to be sticky and shifts in them may lag changes in actual political-military alignments, and voting at the UN General Assembly may not reflect the taking by states of stands on their core security interests. For these reasons, the present writer is part of a research team that is investigating ways by which the new GDELT event-database (Leetaru and Schrodt 2013) might be employed to track shifts in political closeness and distance between countries. 7 Second, we need to identify in greater detail possible causal chains by which, for example, changes in relative power translate into greater ambition or dissatisfaction by a rising power, and associated changes in

\footnotetext{
${ }^{7}$ The research team consists of the present writer, Giacomo Chiozza, Katherine Alexander, and Benjamin Radford.
} 
that state's policies, which in turn might induce target states and others to need to make decisions about their political alignments. In other words, we need to devise better measuring devices for determining whether China is becoming systematically less satisfied with the international status quo, and is willing to pursue assertive if not bellicose policies to change that status quo. Third, in this paper the focus has been on the analysis of possible variation in external balancing by states in the face of growing Chinese power. It would be helpful to complement that focus with a line of inquiry that seeks to ascertain if states are undertaking internal balancing efforts in respect to China, and if they are doing so if they are differing in such efforts, and if that is the case then to account for the variation that is characterizing those efforts.

Recent Chinese actions in regard to the South China Sea and East China Seaincluding confrontations with Philippine and Vietnamese civilian and naval craft in the former, and, in the latter, confrontations with Japanese naval forces and, possibly quite soon, Japanese and U.S. fighter aircraft - raises the question of whether Chinese leaders have reached a decision to try to compel major changes in control of those two vast ocean spaces. Still, there is also a great deal of cooperation that we observe of China, for example, in connection to the management of the continuing problem of North Korea. We need to learn more about China's interests and its satisfaction with the world order, and about the possibilities for peaceful change through diplomacy, even as we track how other countries will react politically and militarily in the years ahead to what is likely to be the growing power of China.

\section{REFERENCES}

Beckman, Robert. 2013. "The UN Convention on the Law of the Sea and the Maritime Disputes in the South China Sea." American Journal of International Law 107(1), 142-163.

Bennett, Scott and Allan Stam. 2008. Eugene: Expected Utility Generation and Data Management Program, Version 3.204. Accessed at http://www.eugenesoftware.org/.

Betts, Richard. 1993/94. "Wealth, Power, and Instability: East Asia and the United States after the Cold War.” International Security 18(3), 34-77.

Bussmann, Margit and John Oneal. 2007. "Do Hegemons Distribute Private Goods? A Test of Power-Transition Theory." Journal of Conflict Resolution 51(1), 88-111.

Choi, Ajin. 2003. "The Power of Democratic Cooperation." International Security 
28(1), 142-153.

Choi, Ajin. 2004. "Democratic Synergy and Victory in War, 1816-1992." International Studies Quarterly 48(3), 663-682.

Christensen, Thomas. 1999. "China, the U.S.-Japan Alliance, and the Security Dilemma in East Asia.” International Security 23(4), 49-80.

Christensen, Thomas. 2006. "Fostering Stability or Creating a Monster? The Rise of China and U.S. Policy Toward East Asia.” International Security 31(1), 81-126.

Christensen, Thomas. 2011. "The Advantages of an Assertive China: Responding to Beijing's Abrasive Diplomacy.” Foreign Affairs (March/April). Accessed at http://www.foreignaffairs.com/articles/ 67477/thomas-jchristensen/the-advantages-of-an-assertive-china.

Clark, Christopher. 2013. The Sleepwalkers: How Europe Went to War in 1914. New York: Harper.

Correlates of War Project. 2010. "National Material Capabilities Data Documentation," Version 4.0 (June). Accessed at http://www.correlatesofwar.org/

Dupuy, Florian and Pierre-Marie Dupuy. 2013. “A Legal Analysis of China's Historic Rights Claim in the South China Sea." American Journal of International Law 107(1), 124-141.

Elman, Colin and Miriam Elman. 1997. "Lakatos and Neorealism: A Reply to Vasquez." American Political Science Review 91(4), 923-936.

Friedberg, Aaron. 1993. "Ripe for Rivalry: Prospects for Peace in a Multipolar Asia." International Security 18(3), 5-33.

Friedberg, Arron. 2005. "The Future of U.S.-China Relations: Is Conflict Inevitable?" International Security 30(2), 7-45.

Friedberg, Arron. 2011. A Contest for Supremacy: China, America, and the Struggle for Mastery in Asia. New York: W.W. Norton.

Gartzke, Erik. 2006. “The Affinity of Nations Index, 1946-2002.” (March), Accessed at http://dss.ucsd.edu/ egartzke/htmlpages/data.html.

Goldstein, Avery. 2005. Rising to the Challenge: China's Grand Strategy and International Security. Stanford: Stanford University Press.

Goldstein, Avery. 2013. "First Things First: The Pressing Danger of Crisis Instability in U.S.-China Relations.” International Security 37(4), 49-89.

Johnston, Alastair. 2007. Social States: China in International Institutions, 1980-200o. Princeton: Princeton University Press.

Johnston, Alastair. 2013. "How New and Assertive Is China's New Assertiveness?" International Security 37(4), 7-48.

Kim, Woosang. 2002. "Power Parity, Alliance Dissatisfaction, and Wars in East Asia, 1860-1993.” Journal of Conflict Resolution 46(5), 654-672. 
Leetaru, Kalev and Paul Schrodt. 2013. "GDELT: Global Data on Events, Location and Tone, 1979-2012." Paper delivered at the Annual Meeting of the International Studies Association, San Francisco, CA. Accessed at http://eventdata.psu.edu/papers.dir/ISA.2013.GDELT.pdf

Lemke, Douglas and Suzanne Werner. 1996. "Power Parity, Commitment to Change, and War." International Studies Quarterly 40(2), 235-260.

Levy, Jack and William Thompson. 2010. "Balancing on Land and at Sea: Do States Ally against the Leading Global Power?" International Security 35(1), 7-43.

Macmillan, Margaret. 2013. The War That Ended Peace: The Road to 1914. New York: Random House.

Mansfield, Edward, Helen Milner and Peter Rosendorff. 2002. "Why Democracies Cooperate More: Electoral Control and International Trade Agreements." International Organization 56(3), 477-514.

Martin, Lisa. 2000. Democratic Commitments: Legislatures and International Cooperation. Princeton: Princeton University Press.

Mearsheimer, John. 2001. The Tragedy of Great Power Politics. New York: W.W. Norton.

Schroeder, Paul. 1994. "Historical Reality vs. Neo-Realist Theory." International Security 19(1), 108-148.

Schweller, Randall. 1997. "New Realist Research on Alliances: Refining, Not Refuting, Waltz's Balancing Proposition.” American Political Science Review 91(4), 927-930

Schweller, Randall. 1998. Deadly Imbalances: Tripolarity and Hitler's Strategy of World Conquest. New York: Columbia University Press.

Signorino, Curtis and Jeffrey Ritter. 1999. "Tau-b or Not Tau-b: Measuring the Similarity of Foreign Policy Positions.” International Studies Quarterly 43(1), 114-144.

Strezhnev, Anton and Erik Voeten. 2013. "United Nations General Assembly Voting Data (Version 7).” Accessed at http://hdl.handle.net/1902.1/ 12379UNF:5:s7mORKL1ZZ6/P3AR5Fokkw== Erik Voeten

Swain, Michael and M. Taylor Fravel. 2011. "China's Assertive Behavior-Part Two: The Maritime Periphery.” China Leadership Monitor 35 (September). Accessed at http://media.hoover.org/sites/default/files/documents/ CLM35MS.pdf

Vasquez, John. 1997. "The Realist Paradigm and Degenerative versus Progressive Research Programs," American Political Science Review 91(4), 899-912. Walt, Stephen. 1987. The Origins of Alliances. Ithaca: Cornell University Press. Walt, Stephen. "The Progressive Power of Realism.” American Political Science 
TheK orean J ournal of International Studies 12-Spedal Issue | 48

Review 91(4), 931-935.

Waltz, Kenneth. 1979. Theory of International Politics. Reading, MA: AddisonWesley.

Waltz, Kenneth. 1997. “Evaluating Theories.” American Political Science Review 91(4), 913-917.

[Received April 2, 2014; Revised April 12, 2014; Accepted May 3, 2014] 